\title{
SOCIAL WELFARE EFFECTS OF PROGRESSIVE INCOME TAXATION UNDER INCREASING INEQUALITY
}

\author{
Saša Ranđelovića, Marko Vladisavljevićb
}

\begin{abstract}
During the 2008 economic crisis, labour market inactivity, unemployment and work informality in Serbia rose substantially, triggering a salient increase in Gini-measured inequality (by $4.3 \mathrm{pp}$ ), while income tax progressivity remained very low. Using the microsimulation and utility function estimation techniques on 2007 and 2012 household survey data for Serbia, we compare the social welfare effects of a hypothetical shift from flat to progressive taxation, before and after the crisis. We find that a shift from flat to progressive tax and the consequent behavioural response lead to a reduction in inequality, a rise in total labour supply and an increase in the overall social welfare in both years. Although the decrease in inequality is higher in 2012, the overall welfare effects are slightly larger in 2007, due to the stronger labour supply response and the stronger disutility of work found in the latter year. This may suggest that a rise in inequality does not per se create a stronger case for progressive taxation, as the welfare effects are considerably driven by the structure of income-leisure preferences.
\end{abstract}

Keywords: Optimal income taxation, tax progressivity, inequality, labour supply, social welfare

JEL Classification: H21, H24, J22

\section{Introduction}

During the 2008 world economic crisis, Serbia reported a severe decline in real GDP, labour market participation and formal employment, while work informality rose. Since most of the effects were taking place at the lower part of the income distribution - market

a University of Belgrade, Faculty of Economics, Belgrade, Serbia

b Institute of Economic Sciences, Serbia

Email: randjelovic@ekof.bg.ac.rs, marko.vladisavljevic@ien.bg.ac.rs 
income - the Gini coefficient in Serbia increased by 4.3 pp from 2007 to 2012, thus becoming one of the largest in Central and Eastern Europe (CEE). In spite of the rising inequality, income tax progressivity in Serbia remained very low. Therefore, the question is whether more progressive taxation would yield a stronger welfare dividend after the crisis, when inequality soared, than before the crisis, when inequality was lower.

Recent empirical literature suggests that a decline in progressivity of the personal income tax is one of the significant drivers of rising inequality in many countries (Stiglitz, 2012; Piketty, 2014; Atkinson, 2015). Assuming that the role of the social planner is to maximize social welfare, which depends on the income size, but also on the way income is distributed, contemporary theory of optimal taxation is balancing between equity and efficiency. If the social welfare is a function of individuals' utilities, which depends on the income-leisure preferences, the social welfare effects of a particular tax scheme are conditional on the underlying distribution of income, as well as on the individuals' preferences regarding income and leisure. Properties of these preferences and related behavioural elasticities are the ones that determine the impact of progressive taxation on social welfare. Although the social welfare function is criticised in the social philosophical literature (Rawls, 1971), as well as in the theoretical literature on social choice (e.g., Sen, 1985), which challenge the underlying assumption that utility is an appropriate indicator of subjective well-being, it is still commonly used in both theoretical and empirical literature on welfare economics.

In this paper, we exploit changes that have taken place in Serbia during the recent crisis in terms of labour market performance and income level and distribution in order to estimate and compare the social welfare effects of a shift from flat income tax to hypothetical progressive income tax in 2007, before the crisis, and in 2012, after the crisis. Our results show that both before and after the crisis, a shift from flat to progressive taxation would have positive social welfare implications, the effects being somewhat larger in 2007 than in 2012. Notwithstanding the fact that the results are driven to some extent by the parameterization of the hypothetical reform scenarios, our findings may also imply that a rise in income inequality does not per se create a stronger case for progressive taxation, as the welfare effects are considerably driven by the structure of income-leisure preferences.

Taking this into account, there are several contributions of the paper. Firstly, we apply a novel approach to the standard methods of welfare analysis to evaluate the effects of progressive taxation, i.e., instead of estimating the welfare-maximizing income tax rates, we compare the social welfare effects of two, equally progressive tax structures, in two different economic settings. Secondly, to the best of our knowledge, this is the first empirical paper on optimal income taxation in a transition economy and also the first 
empirical paper to compare the welfare effects of progressive taxation before and after the crisis, thus contributing to discussion on the impact of the crisis on optimal income tax design.

\section{Inequality and Progressivity - Stylized Facts and Literature Review}

\subsection{Inequality trends in Serbia}

Since the onset of the transition, in the early 2000s, Serbia experienced considerable economic growth, which triggered a decline in inequality and poverty, making them close to the European mean. However, no significant improvement in terms of redistributive effects of tax-benefit policies has been reported, which is why the disposable income inequality in Serbia was still among the highest in Europe. The 2008 world economic crisis and the subsequent Eurozone crisis had a severe impact on the Serbian economy (Table 1). Double recession and structural imbalances, caused by an unfinished transition to a market economy, triggered a strong deterioration of labour market parameters, a rise in unemployment, with work informality and inactivity being considerably more pronounced than in CEE and the EU.

Table 1: Macroeconomic and inequality indicators, 2007-2012 (in pp)

\begin{tabular}{l|c|c|c|c}
\hline & $\boldsymbol{\Delta}$ Real GDP & $\boldsymbol{\Delta}$ Participation rate & $\boldsymbol{\Delta}$ Unemployment rate & $\boldsymbol{\Delta}$ Market income Gini \\
\hline Serbia & -2.2 & -3.2 & 5.8 & 4.3 \\
\hline EU-28 & -1.1 & 1.3 & 3.3 & 0.5 \\
\hline CEE & 2.0 & 2.2 & 2.2 & 0.8 \\
\hline
\end{tabular}

Source: World Bank Database and authors' calculations

Due to structural changes in the economy, which hit the lower income cohorts in particular, market income inequality in Serbia, reported in the household surveys, rose considerably from 2007 to 2012. According to the Survey on Income and Living Conditions (SILC), in 2012 the market income Gini coefficient stood at 0.55, which was higher than the EU and CEE mean (Figure 1). A similar rise in market inequality has been reported only by a few more European countries that were severely struck by the global crisis (Ireland, Spain, Latvia and Cyprus). 
Figure 1: Market income Gini coefficient in CEE, 2007-2012

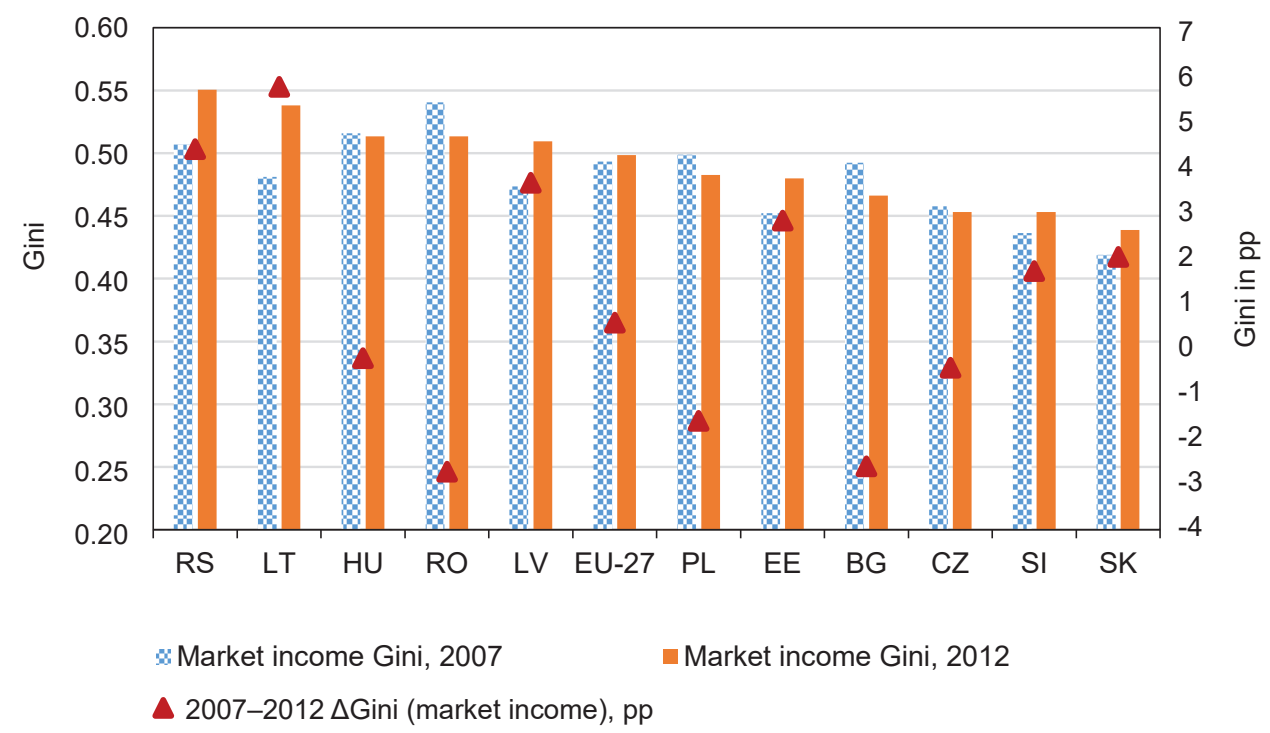

Source: Authors' calculations based on EUROMOD database

The government in Serbia responded to rising inequality by strengthening the meanstested benefits, while the degree of income tax progressivity remained almost unchanged. The RE index, which the shows percentage point decline in the Gini coefficient due to taxation, stood at 0.96 in 2007 and 1.06 in 2012. Therefore, the income tax progressivity in Serbia was the second lowest in Europe, at the same time being almost four times lower than the EU average and more than twice lower compared to the CEE average. In spite of the low tax progressivity, the labour market participation rate in Serbia was among the lowest in CEE, especially in the case of low wage earners, primarily due to high activation costs (Arandarenko and Vukojević, 2008; Žarković-Rakić et al., 2016).

\subsection{Inequality and tax progressivity}

According to the standard optimal taxation theory, a tax system should be designed to maximize the social welfare function subject to a set of constraints. However, the definition and interpretation of a social welfare function has evolved considerably over time, thus modifying the view on the optimal income tax structure. If utility depends only on income, the marginal utility of income being diminishing and labour supply elasticity being zero, progressive taxation, aimed at fully equalizing the disposable income 
is welfare-maximizing (Edgeworth, 1897). However, Mirrlees (1971) has challenged this concept by assuming that taxation may trigger labour supply reaction and thus concluded that a combination of linear and negative income tax is optimal. Mirrlees has assumed unit labour supply elasticity and proposed top marginal tax rates lower than 40 percent, which was considered low at that time. At the same time, the view on the social welfare function has also evolved, arguing that the social welfare depends positively on the income level, but also on its distribution - the higher the inequality, the lower the social welfare (Sen, 1973).

Building on Mirrlees's framework, Stern (1976) investigated a set of utility functions and evaluated the sensitivity of linear taxation to specification of the social welfare function and variation in the revenue requirements, concluding that the optimal tax rates rise in aversion towards inequality and revenue requirements. Arguing that the labour supply response in Mirrlees's calculations are overstated, Stern (1976) estimated a labour supply elasticity of 0.4 and concluded that the optimal top marginal tax rate exceeds 50 percent. By varying the specification of the social welfare function and the social planners' aversion to inequality, Stern (1987) concluded that the optimal marginal tax rates range from 19 percent to 80 percent (the latter is the case of the Rawlsian social welfare function).

Subsequent theories of optimal taxation have evaluated the interlink between inequality and taxable income, and argued that top marginal tax rate cuts may incentivize high earners to work more, thus widening the gap in income distribution (Lindsey, 1987; Feldstein, 1995). Although taxation literature since Mirrlees (1971) has considered labour supply response an important parameter of the optimal tax scheme, the relationship between labour supply elasticity and optimal tax rates was only formalized by Saez (2001). Based on that, Gruber and Saez (2002) showed that taxable income elasticity rises with income, thus suggesting that optimal tax structures may feature tightly targeted transfers to lower income taxpayers and flat or even declining marginal tax rates for middle and high-income taxpayers.

Empirical literature suggests that income inequality in Europe was on the rise in the last few decades, which was associated with a decline in tax progressivity (Atkinson, 2015; Dabla-Norris, 2015). To explain dynamics in tax progressivity, more recent papers have taken into account preferences, technology and market structure as key drivers of economic forces which shape the degree of progressivity. Thus, Heathcote et al. (2017) find that endogenous skill investment, flexible labour supply and propensity to finance government outlays play a significant role in limiting optimal progressivity and show that the tax system in the USA is still more progressive than it would have been advised by the welfare-maximizing social planner, which is explained by the below-average propensity to skill investment of the median voter. 
As the decision on tax progressivity is a matter of public choice, change in income distribution may also have an influence on tax policy decisions. According to the 'MeltzerRichard model', greater inequality is expected to enhance redistributive policies through the poorer median voter, while the 'Moene-Wallerstein model' would suggest the opposite. Verbist and Figari (2014) use 1998-2008 data for EU-15 countries and find evidence on the 'Moene-Wallerstein model', which implies that more unequal European societies demand less redistribution (lower tax burden and less steep progressivity). They also find a negative correlation between progressivity and tax level. However, this result cannot be generalized for all European countries, as there are studies dealing with selected $\mathrm{CEE}$ countries (e.g., Slovenia) and showing that a rise in market income inequality was associated with rising tax progressivity, which is why inequality of employees' after-tax earnings remained fairly stable in the last few decades (Stanovnik and Verbič, 2013).

\section{Research Design, Data and Methodology}

To evaluate the social welfare effects of progressive taxation, we first estimate the (incomeleisure) utility function, within the discrete labour supply framework. In the next step, we impose new budget constraints (under the hypothetical tax reform scenarios - flat and progressive) and estimate the labour supply reaction to the shift from flat to progressive tax. New working hours (after labour supply reaction) and corresponding disposable incomes are then assessed, enabling computation of the post-treatment utilities and the respective social welfare indicators.

To evaluate the effects of progressive taxation, we use the 2007 Living Standard Measurement Survey (LSMS) and 2012 SILC data, collected by the Statistical Office of the Republic of Serbia (SORS) on a representative sample of households. ${ }^{1}$ In both periods, the data are collected on the household and the individual level. Since both datasets stem from the class of representative living standard surveys, their structures, in terms of the sample, type and structure of questions are rather similar (SORS, 2008; 2015).

In accordance with the common approach in optimal taxation literature (Mirrlees, 1971; Mankiw et al., 2009), we employ a utilitarian social welfare function (Equation 1), which depends on individuals' income $\left(Y_{i}\right)$, leisure $\left(L_{i}\right)$ and the vector of social and economic characteristics $\left(Q_{i}\right)$.

$$
S W_{u}=\sum_{i=1}^{n} U_{i}\left(Y_{i}, L_{i}, Q_{i}\right)
$$

1 LSMS contains data on 5,575 households (17,735 individuals). SILC (based on Eurostat methodology), contains data on 6,501 households (20,069 individuals). 
To test the robustness of the results on the degree of aversion towards inequality, we also estimate the effects using a more egalitarian social welfare function (Equation 2). In that respect, we use the results of Spadaro et al. (2012), who solve the optimal inverse problem and find that in the social welfare function of developed European countries, weights assigned to the non-bottom quintiles are flat, while those for the bottom quintile are higher by $1 / 2$.

$$
S W_{e}=\sum_{i=1}^{n} \mu U_{i}\left(Y_{i}, L_{i}, Q_{i}\right) \quad \mu= \begin{cases}1.5, & 1 \text { st quintile } \\ 1, & \text { 2nd }-5 \text { th quintiles }\end{cases}
$$

The income-leisure utility function, with discrete labour supply choice, is estimated following the approach of van Soest (1995) and Blundell et al. (2000), using a sample of individuals who can be flexible on the working hours and for whom the working hours and wage rate can be identified. In accordance with the standard practice in labour supply modelling (Blundell et al., 2000), individuals under the age of 18 and over the age of 64, students, pensioners, persons with disabilities and women on maternity leave are omitted from the sample. We also exclude agricultural workers and unpaid family members due to limitations in terms of their working hour measurement. The final samples for the estimation of the utility function parameters contain 7,573 individuals in 2007 and 8,839 individuals in 2012 (Appendix A1).

For singles, we estimate the utility function parameters, assuming that the individuals can choose to be inactive or to work 20,40 or 50 hours per week, in either a formal or an informal sector, and earn corresponding wages:

$$
\begin{aligned}
& U_{i j k}=\alpha_{1} Y_{i j k}+\alpha_{2} Y_{i j k}{ }^{2}+\alpha_{3} L_{j}+\alpha_{4} L_{j}^{2}+\alpha_{5} N_{i}+\alpha_{6} I_{i}+\beta_{l} X_{l}+v_{i j k} \\
& Y_{i j k}=f\left(w_{i k} * H_{j}, Z_{i j k}\right) \\
& i=1,2, \ldots n ; j=0,20,40,50 ; k=N, I, F
\end{aligned}
$$

The utility function depends on disposable income $\left(Y_{i j k}\right)$, leisure $\left(L_{j}\right)$, and sectoral choice $-N_{i}$ (non-participation) or $I_{j}$ (work in informal sector). ${ }^{2}$ Disposable income, calculated in the tax-benefit microsimulation model (SRMOD), is the sum of the individual's monthly wage (product of chosen working hours $H_{j}$, and individual sector hourly wage rate $w_{i k}$ ) and other household incomes $\left(Z_{i j k}\right)$, such as capital income, pensions, benefits, etc. We take into account the observed heterogeneity by introducing an interaction term $\left(X_{l}\right)$ of the main variables (income, leisure, informal and non-participation) with observed individual and family characteristics (e.g., presence of children under 6 years of age, marital status, age,

2 Formal sector is omitted to avoid multicollinearity. 
gender, etc.). We also introduce a stochastic part of the utility function $\left(v_{j i k}\right)$ to account for individual departures from the observed features of the utility function, following the approach proposed by Bourguignon and Gurgand (2001).

Since couples are assumed to optimize their labour-income decisions jointly, the utility function for coupled individuals is estimated separately from singles ( $m$ and $f$ subscripts representing the variables for males and females accordingly, while $i$ stands for the couple):

$$
\begin{aligned}
& U_{i j k}=\alpha_{1} Y_{i j k}+\alpha_{2} Y_{i j k}{ }^{2}+\alpha_{3} L_{j f}+\alpha_{4} L_{j f}{ }^{2}+\alpha_{5} L_{j m}+\alpha_{6} L_{j f}{ }^{2}+\alpha_{7} I_{f}+\alpha_{8} I_{m}+\beta_{l} X_{l}+v_{i j k} \\
& Y_{i j k}=f\left(w_{i k f} * H_{j f}, w_{i k m} * H_{j m}, Z_{i j k}\right) \\
& i=1,2, \ldots, n ; j=0,40(I), 40(F), 50(F) ; k=N, I, F
\end{aligned}
$$

Discrete choice alternatives for couples (as well for singles) are created starting from the empirical distribution of working hours. Therefore, utility function parameters for coupled individuals are estimated assuming that they can make four discrete (labour) choices -0 hours, 40 working hours in the informal sector, 40 and 50 working hours in the formal sector, thus allowing sixteen alternatives.

During the observed period, the share of informal work in the total employment in Serbia rose from 13 to 17 percent. Therefore, the informal work issue needs to be taken into account; we do it by controlling the estimation of the utility function parameters for sectoral choices, such as informal sector work, following the approach of Bargain (2000) and De Hoyos (2012). Thus, we also take into account the effects of tax reform on work formalization, which is important because disutility of informal work is stronger than in the case of formal work (Pauna, 2004; Albrecht et al., 2009; Žarković-Rakić et al., 2016).

Since we observe no wages of unemployed and inactive individuals, we impute them by using the selmlog procedure (Bourguignon et al., 2007). ${ }^{3}$ Additionally, we introduce a stochastic component in the wage prediction, which is estimated by means of a random draw from a normal distribution, with the observed variance (as suggested by Löffler et al., 2014). Predicted wages are then used to calculate disposable incomes for each individual and couple and each hours/sector alternative.

Maximum likelihood estimation is applied to the conditional logit function to estimate the utility function parameters (McFadden, 1974; Blundell et al., 2000). As the data are

3 Wages are predicted assuming to them be are conditional on education, work experience, region, settlement, and the sector selection variables derived from the first-stage mlogit sector selection model. Age, marital status, number of children, regional unemployment rate and pension are used as the sector choice predictors. Estimated parameters are in accordance with theoretical expectations. Results available upon request. 
grouped by individual/couple (within-group variation representing a set of available alternatives), the likelihood is calculated relative to each group. We use the clogit $^{4}$ procedure in Stata to estimate the coefficients. Both level and second-order preference parameters for income and leisure have been used. Following Bourguignon and Gurgand (2001), the stochastic part of the utility function $\left(v_{j i}\right)$ is estimated by making 200 random draws from the Halton distributions.

\section{Reform Scenarios}

The hypothetical tax reform scenarios are simulated using the tax-benefit microsimulation model-SRMOD, which is based on the EUROMOD platform (Ranđelović and ŽarkovićRakić, 2013). The hypothetical progressive tax reform scenarios are designed under two restrictions - revenue neutrality and an equal degree of progressivity in the two periods. Revenue neutrality allows us to control the results for the effects of income on social welfare. ${ }^{5}$ The progressive tax scenarios are calibrated to yield a relatively modest degree of progressivity in both years (RE index of 2.6), which is only slightly higher than the CEE mean, but still considerably smaller than in developed European countries. Since the income concentration in Serbia is very high, relative to the EU mean, the difference being especially pronounced in the top decile ${ }^{6}$, the tax brackets under the progressive tax scenarios are designed to provide redistribution from the top decile to the lower income levels.

Calibration of the reform scenarios is performed assuming that the taxable income consists of wages, self-employment income, freelance contract income, capital income (interests, dividends, rents) and other incomes, while pensions and benefits are not taxable. Under both the 2007 and 2012 progressive tax scenarios, taxable income up to one half of the average wage (AW), which is equivalent to the minimum wage, is exempted from taxation, while the total number of tax brackets is made equal to the EU average (Table 2). Under the flat tax scheme, all these incomes are taxed at a uniform marginal tax rate.

4 The clogit procedure is the Stata function based on McFadden's (1974) original work. Detailed explanation of the conditional logit can be found in Green (2012, chapter 17).

5 Although the total budget constraints are constant under both scenarios, the individual budget constraints may change due to altered tax structure (Appendix A2a and A2b).

6 Statistics available upon request. 
Table 2: Tax reform scenarios

\begin{tabular}{l|c|c|c|c}
\hline \multirow{2}{*}{$\begin{array}{l}\text { Tax brackets/marginal } \\
\text { tax rates }\end{array}$} & \multicolumn{2}{|c|}{2007} & \multicolumn{2}{c}{2012} \\
\cline { 2 - 5 } & Flat tax & Progressive tax & Flat tax & Progressive tax \\
\hline $\mathbf{0 . 5}$ AW & 10.5 & 0 & 10.6 & 0 \\
\hline $\mathbf{1 ~ A W}-\mathbf{1 . 5}$ AW & 10.5 & 15.3 & 10.6 & 15.1 \\
\hline $\mathbf{1 . 5}$ AW - 3 AW & 10.5 & 21 & 10.6 & 23 \\
\hline $\mathbf{3}$ AW & 10.5 & 31 & 10.6 & 33 \\
\hline RE index & 10.5 & 41 & 10.6 & 43 \\
\hline
\end{tabular}

Note: $\mathrm{AW}$ is the average wage in the respective period.

Source: Authors' calculations.

\section{Results}

\subsection{Labour supply and income redistribution effects}

The results of the 2007 and 2012 utility function estimates suggest a positive impact of income and leisure on utility, but at diminishing rates (Tables 3 and 4). The estimated parameters of the total and marginal utility of income and leisure have the expected signs, comparable with the results obtained in other empirical studies (e.g., Mascarola et al., 2015; Figari, 2015).

Due to the change in preferences over birth cohorts and change in the sociodemographic structure, estimated parameters changed slightly from 2007 to 2012, which is in line with the findings of Heim (2007) and Bargain et al. (2000) for Europe and the USA. 
Table 3: Utility function parameters - singles

\begin{tabular}{|c|c|c|c|c|}
\hline \multirow[b]{2}{*}{ Variables } & \multicolumn{2}{|c|}{2007} & \multicolumn{2}{|c|}{2012} \\
\hline & coef. & se & coef. & se \\
\hline Disposable income (DI) & $0.586^{* * *}$ & $(0.120)$ & $0.369^{* * *}$ & $(0.105)$ \\
\hline$D I * A g e$ & 0.001 & $(0.002)$ & $0.005^{* *}$ & $(0.002)$ \\
\hline$D I *$ Married & 0.040 & $(0.041)$ & $0.096^{* * *}$ & $(0.028)$ \\
\hline DI*Preschool children & $0.263^{* * *}$ & $(0.067)$ & $0.153^{* * *}$ & $(0.047)$ \\
\hline DI Squared & $-1.557^{* * *}$ & $(0.411)$ & $-0.473^{* * *}$ & $(0.126)$ \\
\hline Leisure & $0.239^{* * *}$ & $(0.027)$ & $0.542 * * *$ & $(0.027)$ \\
\hline Leisure*Age & $0.001^{* * *}$ & $(0.000)$ & $0.002 * * *$ & $(0.000)$ \\
\hline Leisure squared & $-0.353^{* * *}$ & $(0.030)$ & $-0.716^{* * *}$ & $(0.032)$ \\
\hline Informal employment (IE) & $-1.769^{* * *}$ & $(0.100)$ & $-0.847^{* * *}$ & $(0.079)$ \\
\hline IE part time & $1.976^{* * *}$ & $(0.191)$ & $2.221^{* * *}$ & $(0.182)$ \\
\hline IE*Female & $-0.908^{* * *}$ & $(0.176)$ & $-1.035^{* * *}$ & $(0.123)$ \\
\hline Non-participants (NP) & $8.209 * * *$ & $(0.594)$ & $13.821^{* * *}$ & $(0.704)$ \\
\hline$N P * A g e$ & $-0.023^{* * *}$ & $(0.009)$ & $-0.042^{* * *}$ & $(0.009)$ \\
\hline NP*Preschool children*Female & $0.836^{* * *}$ & $(0.191)$ & $0.861^{* * *}$ & $(0.181)$ \\
\hline Observations & 23,352 & - & 28,112 & - \\
\hline r2_p & 0.26 & - & 0.3 & - \\
\hline II & $-2.12 \mathrm{e}+06$ & - & -2050000 & - \\
\hline
\end{tabular}

Note: Robust standard errors in parentheses. ${ }^{* * *} p<0.01,{ }^{* *} p<0.05,{ }^{*} p<0.1$

Source: Authors' calculations. 
Table 4: Utility function parameters - couples

\begin{tabular}{|c|c|c|c|c|}
\hline \multirow[b]{2}{*}{ Variables } & \multicolumn{2}{|c|}{2007} & \multicolumn{2}{|c|}{2012} \\
\hline & coef. & se & coef. & se \\
\hline Disposable income (DI) & $2.147^{* * *}$ & $(0.233)$ & $1.407^{* * *}$ & $(0.149)$ \\
\hline DI*Leisure - women & $-6.164^{* * *}$ & $(0.920)$ & $-0.002^{* * *}$ & $(0.001)$ \\
\hline DI*Leisure - men & $-0.006^{* * *}$ & $(0.001)$ & $-0.002^{* * *}$ & $(0.001)$ \\
\hline DI*Age - women & $-0.003^{* * *}$ & $(0.001)$ & $-0.006^{* * *}$ & $(0.002)$ \\
\hline DISquared & $-0.008^{* *}$ & $(0.003)$ & $-1.746^{* * *}$ & $(0.406)$ \\
\hline Leisure-women & $0.271^{* * *}$ & $(0.022)$ & $0.384^{* * *}$ & $(0.022)$ \\
\hline Leisure squared - women & $-0.181^{* * *}$ & $(0.017)$ & $-0.272^{* * *}$ & $(0.017)$ \\
\hline Leisure-men & $0.088^{* * *}$ & $(0.019)$ & $0.208^{* * *}$ & $(0.020)$ \\
\hline Leisure - men*Age - men & $-0.071^{* * *}$ & $(0.014)$ & $0.001^{* * *}$ & $(0.000)$ \\
\hline Leisure squared - men & $0.001^{* * *}$ & $(0.000)$ & $-0.162^{* * *}$ & $(0.014)$ \\
\hline Informal employment - women & $-2.250^{* * *}$ & $(0.137)$ & $-1.682^{* * *}$ & $(0.104)$ \\
\hline Informal employment - men & $-1.310^{* * *}$ & $(0.088)$ & $-0.791^{* * *}$ & $(0.074)$ \\
\hline Non-participants - women *Preschool children & $0.644^{* * *}$ & $(0.124)$ & $0.499^{* * *}$ & $(0.111)$ \\
\hline Observations & 33,232 & - & 36,960 & - \\
\hline r2_p & 0.17 & - & 0.17 & - \\
\hline II & $-2.10 e+06$ & - & $-1,900,000$ & - \\
\hline
\end{tabular}

Note: Robust standard errors in parentheses. ${ }^{* *} p<0.01,{ }^{* *} p<0.05,{ }^{*} p<0.1$.

Source: Authors' calculations.

Since informal work makes up a considerable part of the total labour supply in Serbia, we account for it by estimating the impact of work informality on individual utility. The results indicate disutility from informal employment in both years, the estimated parameters for the informal work being higher before than after the crisis, which may be caused by the fact that informal work became more common during the crisis.

Estimated labour supply elasticities (Table 5) at both the extensive and the intensive margin are within the range of findings in the other empirical literature (Bargain et al., 2000). Our results also suggest moderate formalization elasticities in both years. All three coefficients of elasticity are higher in 2012 than in 2007, which may be explained by a variation in the sample preferences due to changes in social and economic properties of the estimation sample, as suggested by Heim (2007) and Bargain et al. (2000). 


\begin{tabular}{l|c|c|c|c}
\hline \multirow{2}{*}{} & \multicolumn{2}{|c|}{ Singles } & \multicolumn{2}{c}{ Couples } \\
\cline { 2 - 5 } & $\mathbf{2 0 0 7}$ & $\mathbf{2 0 1 2}$ & $\mathbf{2 0 0 7}$ & 2012 \\
\hline Elasticity at extensive margin & 0.418 & 0.827 & 0.489 & 0.739 \\
\hline Elasticity at intensive margin & 0.034 & 0.062 & 0.033 & 0.043 \\
\hline Formal-informal work elasticity & 0.168 & 0.372 & 0.199 & 0.320 \\
\hline
\end{tabular}

Source: Authors' calculations.

Results on the effects before labour supply reaction, presented in Figure 2, show that in both years, a shift from flat to progressive tax would trigger a redistribution of after-tax income from the top decile (in 2012 also from the $9^{\text {th }}$ decile) to the lower deciles.

Figure 2: Change in the after-tax income, before labour supply reaction (in percent)

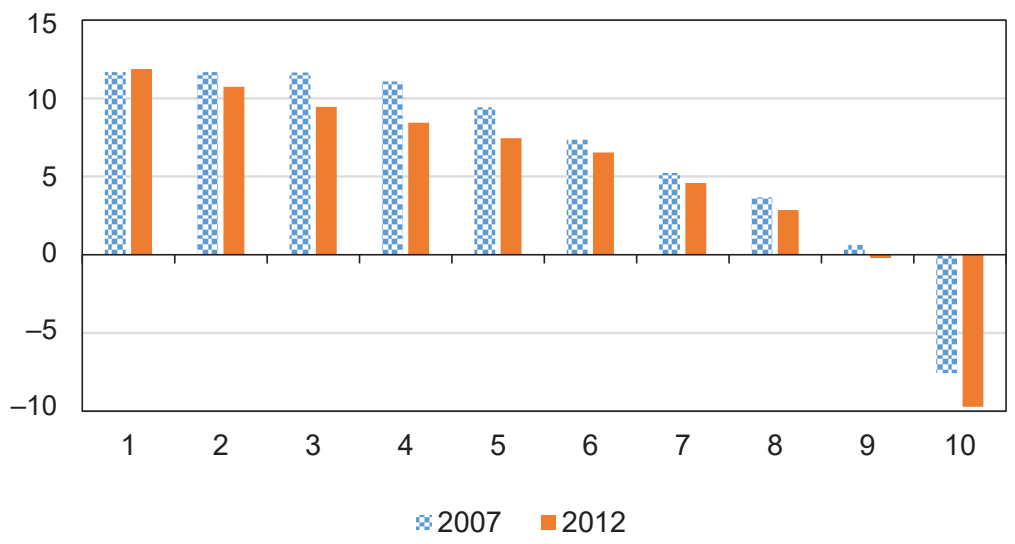

Source: Authors' calculations.

The results, presented in Table 6, show that mean weekly working hours would rise in both years after the reform, the increase being slightly stronger in 2012 than in 2007 , reflecting larger labour supply elasticities. When translated into full-time job equivalents, a shift from flat to progressive income tax would trigger creation of approximately 66 thousand jobs in 2012 and 53.8 thousand jobs in 2007.

The labour supply effects are positive in both years, since the increase in working hours in the lower parts of the income distribution outperforms the decline in the labour 
supply at the top of the income distribution (Figure 3). This indicates that when income concentration is very high ${ }^{7}$, it is possible to attain considerable redistribution of tax burden to high-income earners, thus limiting the negative labour supply response to relatively small cohort and enabling positive labour supply reaction of a large part of the working population.

Table 6: Labour market effects - working hours

\begin{tabular}{|c|c|c|c|c|}
\hline Year & Variable & $\begin{array}{l}\text { Observations } \\
\text { (weighted) }\end{array}$ & $\begin{array}{c}\text { Mean } \\
\text { (weekly) }\end{array}$ & $\begin{array}{c}\text { Full-time jobs } \\
\text { equivalent }\end{array}$ \\
\hline \multirow{3}{*}{2007} & Flat tax & $3,295,124$ & 28.46 & $2,344,388$ \\
\hline & Progressive tax & $3,295,124$ & 29.11 & $2,398,229$ \\
\hline & Difference & - & 0.65 & 53,842 \\
\hline \multirow{3}{*}{2012} & Flat tax & $3,151,270$ & 25.75 & $2,028,875$ \\
\hline & Progressive tax & $3,151,270$ & 26.59 & $2,094,899$ \\
\hline & Difference & - & 0.84 & 66,025 \\
\hline
\end{tabular}

Source: Authors' calculations.

Figure 3: Labour supply reaction by decile - change in working hours per week (in percent)

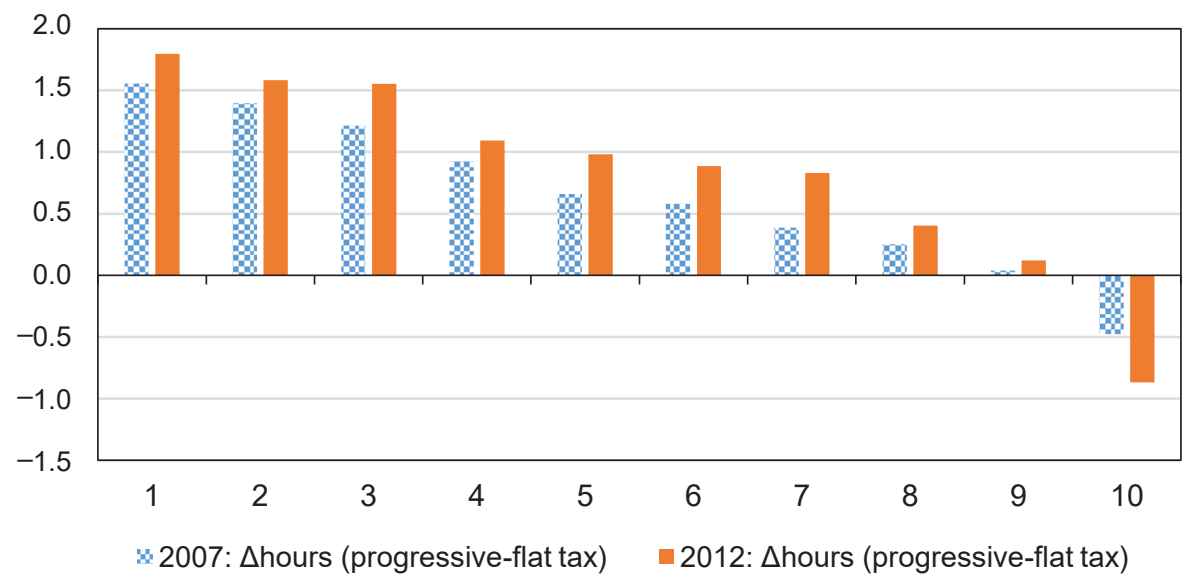

Source: Authors' calculations.

7 Approximately 38 percent of the disposable income in Serbia is owned by the $10^{\text {th }}$ decile. 
Redistribution of the tax burden may also trigger sizeable formalization effects, which is in accordance with Allingham and Sandmo's (1972) tax evasion model and empirical findings on this topic (Clotfelter, 1983; Alm, 1992). In both 2007 and 2012, the probability of informal work after introduction of progressive tax would decline, which is linked to the rise in formal work; the decrease is 2 percent in 2007 and 2.7 percent in 2012 (Table 7). Formalization effects are larger in 2012 than in 2007 due to larger formalization elasticities (Table 5).

Table 7: Work formalization effects - probabilities of each discrete choice

\begin{tabular}{l|l|c|c|c}
\hline \multirow{2}{*}{ Year } & \multicolumn{1}{|c|}{ Choice } & $\begin{array}{c}\text { Flat tax } \\
\text { (percent) }\end{array}$ & $\begin{array}{c}\text { Progressive tax } \\
\text { (percent) }\end{array}$ & $\Delta$ (pp) \\
\hline \multirow{3}{*}{2007} & non-participation (NP) & 34.1 & 32.5 & -1.60 \\
\cline { 2 - 5 } & informal work (INF) & 8.7 & 8.4 & -0.37 \\
\cline { 2 - 5 } & formal work (F) & 57.2 & 59.1 & 1.98 \\
\hline \multirow{2}{*}{2012} & non-participation (NP) & 39.0 & 36.9 & -2.12 \\
\cline { 2 - 5 } & informal work (INF) & 10.6 & 10.0 & -0.56 \\
\cline { 2 - 5 } & formal work (F) & 50.5 & 53.2 & 2.68 \\
\hline
\end{tabular}

Source: Authors' calculations.

In both years, the labour market activation effects are larger in the lower part of the income distribution, while the formalization effects are approximately equal from the $1^{\text {st }}$ to the $8^{\text {th }}$ decile. In both years, non-participation and informal work would rise after the reform in the top decile, while the probability of formal work would drop. The decline in formal work in the top decile is mostly attributed to individuals working overtime, which may indicate a substitution effect in this cohort. The effects of progressive taxation on the surge in informality and non-participation and on the decline in formal work in the top decile are slightly stronger in 2012 than in 2007, reflecting the difference in formalization elasticities.

The redistribution of the tax burden and the consequent labour supply reaction would result in a surge of the total disposable income in 2007 and 2012, by 2.6 percent and 3.3 percent respectively, the increase being strong in the lower part of the income distribution, modest at the middle and negative at the top of the income distribution (Figure 4). Disposable income of the top decile would decline slightly in both 2007 and 2012, due to a rise in the tax wedge and decline in labour supply. Therefore, the stronger rise in the total disposable income in 2012 compared to 2007 is mostly the consequence of stronger labour supply reaction in 2012. 
Figure 4: Change in disposable income after labour supply reaction (percent)

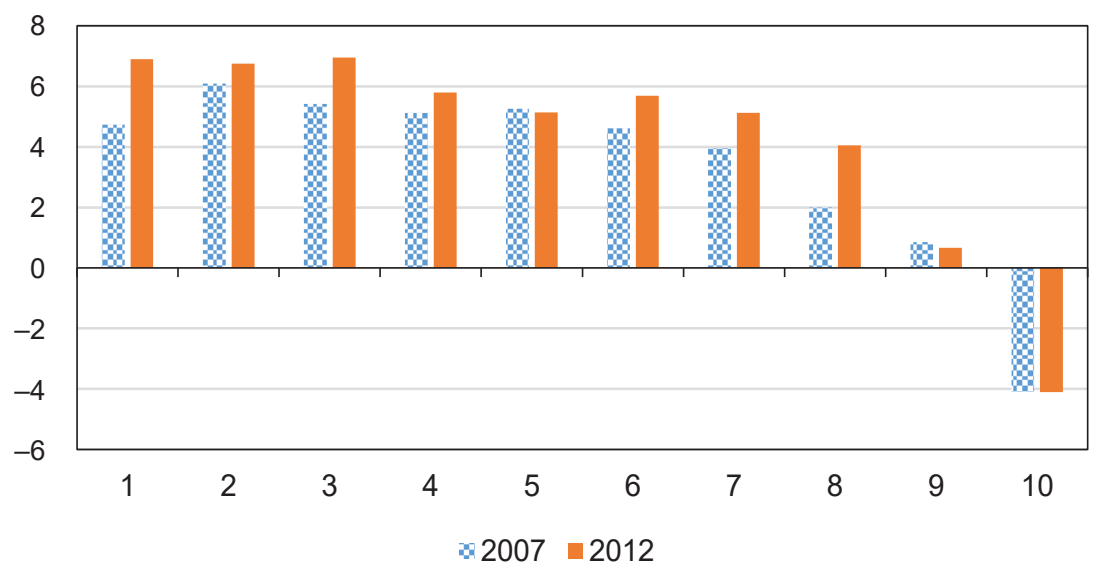

Source: Authors' calculations.

The tax reform would affect income distribution via two channels. Firstly, changes in the tax structure trigger progressive redistribution of income. Secondly, changes in the after-tax income trigger progressive labour supply reaction - labour activation of low-income earners and deactivation of high-income earners. Thus, changes to the tax system and subsequent behavioural reaction reduce inequality considerably (Table 8). In both years, the direct impact of the increase in tax progressivity on the Gini coefficient was larger than the second-round (labour supply) effect. However, progressive labour supply reaction contributes to further reduction in the Gini coefficient too. It should also be noted that equalizing effects of labour supply reaction to tax reform was stronger in 2012 than in 2007 due to larger elasticities.

Table 8: Effects on Gini coefficient (in pp)

\begin{tabular}{c|c|c}
\hline$\Delta$ Gini - due to... & $\mathbf{2 0 0 7}$ & $\mathbf{2 0 1 2}$ \\
\hline ...rise in tax progressivity & -1.4 & -1.4 \\
\hline$\ldots$ labour supply reaction & -0.4 & -0.7 \\
\hline Total change in Gini & -1.8 & -2.1 \\
\hline
\end{tabular}

Source: Authors' calculations. 


\subsection{Social welfare effects}

A shift from a flat to progressive tax scheme triggers a slight rise in the (utilitarian) social welfare in both years, the effects being somewhat stronger in 2007 (Table 9). The results are robust to changes in specifications of the social welfare function, as a switch to the egalitarian specification has very mild effects on the social welfare effects.

Table 9: Social welfare effects

\begin{tabular}{|c|c|c|c|c|}
\hline \multirow{2}{*}{ Year } & \multirow{2}{*}{ Variable } & \multirow{2}{*}{ Mean (weekly) } & \multicolumn{2}{|c|}{ Total social welfare } \\
\hline & & & Utilitarian & Egalitarian \\
\hline \multirow{3}{*}{2007} & Flat tax & 22.78 & $75,061,164$ & $74,828,521$ \\
\hline & Progressive tax & 22.91 & $75,482,474$ & $75,256,286$ \\
\hline & Difference (in percent) & - & 0.56 & 0.57 \\
\hline \multirow{3}{*}{2012} & Flat tax & 23.23 & $73,203,071$ & $73,035,567$ \\
\hline & Progressive tax & 23.32 & $73,481,069$ & $73,318,681$ \\
\hline & Difference (in percent) & - & 0.38 & 0.39 \\
\hline
\end{tabular}

Source: Authors' calculations.

In both years, the tax reform leads to a rise in the total working hours, thus triggering an increase in disposable income and its considerable redistribution. While the increase in the working hours has adverse effects on utility, the impact of the increase in disposable income and its progressive redistribution on utility is positive. Therefore, the net positive social welfare effects suggest that the positive effects of the rise in income and its redistribution prevail over the disutility effects of the increase in working hours.

The results also suggest that the social welfare effects are stronger in 2007 than in 2012, although the inequality was larger in the latter year. This result may be explained by the stronger labour supply reaction in 2012 (with negative effects on utility) and higher disutility effects of work in 2012 compared to 2007.

The distribution of the social welfare effects by income level is consistent with the distribution of labour supply and disposable income effects. In 2007 as well as in 2012, the tax reform triggers a rise in welfare in the non-top deciles, while the welfare of the top-decile income earners drops (Figure 5). Under the utilitarian specification, the increase in welfare is almost even across the non-top deciles, while under the egalitarian specification, the two lowest deciles report larger gains in well-being than the remaining deciles in both years (Figure 5 and Appendix A3). 


\section{Figure 5: Social welfare effects by decile (percent change) - utilitarian specification}

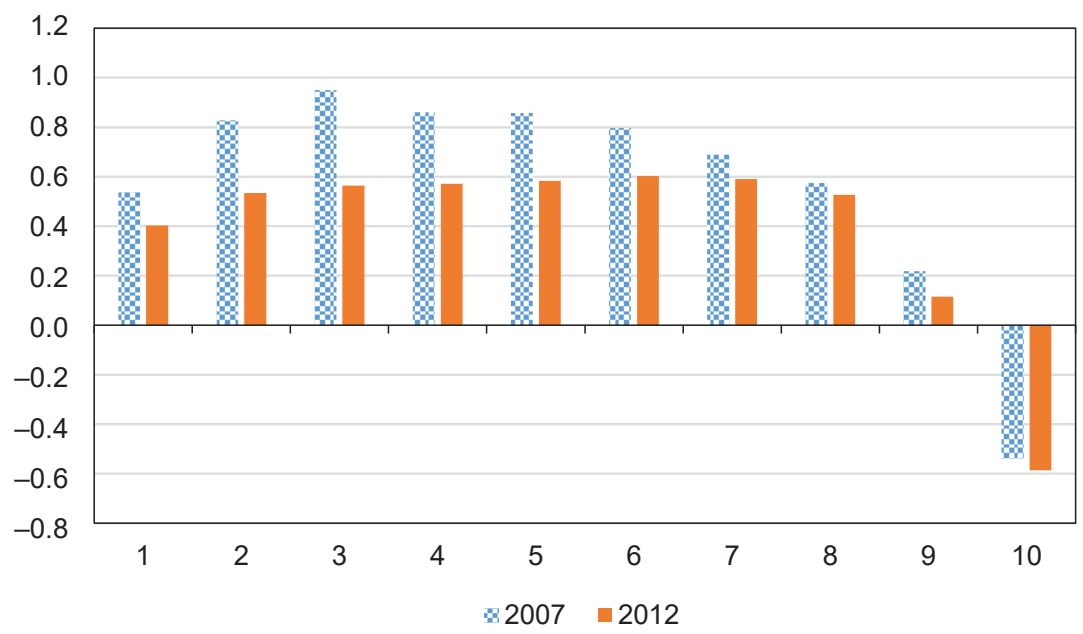

Source: Authors' calculations.

\section{Conclusion}

The 2008 world economic crisis and its economic and political consequences have brought income distribution back into the focus of economic theory and policy in general. During the crisis, the income inequality in Serbia reported a salient rise, which makes the issue of optimal taxation even more relevant. In this paper, we estimate inequality, labour supply and the overall social welfare effects of a shift from flat income tax to hypothetical progressive income tax and exploit the change in income distribution (and work informality) that took place during the crisis in order to evaluate whether the higher inequality and informality have created a stronger case for progressive income taxation.

Our results show that a shift from flat to progressive tax in both 2007 and 2012 would trigger a positive labour supply response with negative welfare effects, i.e., a strong rise in the working hours in the lower part of the income distribution, which overrides the decline in labour supply at the top of the income distribution. However, a rise in labour supply would boost the total disposable income, thus improving welfare. The tax reform would also trigger strong redistribution of income from the top decile to the lower parts of the income distribution, which is attained through progressive redistribution of tax burden, but also through progressive labour supply response. The results indicate that the inequality-reducing effects of a shift to progressive tax are stronger in 2012, when income inequality was higher. Inequality-reducing income redistribution yields positive 
welfare effects, since in both years the marginal utility of income is steeply diminishing. As the net result of these (three) effects, a shift from flat to progressive tax would lead to an increase in social welfare in both years, since the positive effects of the rise in disposable income and its progressive redistribution would override the negative effects of the rise in working hours. The positive social welfare effects are concentrated in the lower part of the income distribution, while the welfare of top-decile individuals would deteriorate. These results indicate that when income concentration is very high, shifting the tax burden to the decile with the highest income concentration may be both equity and efficiency-enhancing.

Although the inequality-reducing effects are stronger in 2012, the net social welfare gain would be somewhat larger in 2007 due to the stronger labour supply reaction and stronger disutility of work in 2012 compared to 2007. The higher disutility of work (relative to leisure) in 2012 may be a consequence of more difficult working conditions, which are linked to overall deterioration of economic performance. Provided that the difference in welfare effects is large enough, it may imply that a rise in income inequality does not per se create a stronger case for progressive taxation, as the welfare effects are also considerably driven by the structure of income-leisure preferences.

Although the estimated social welfare effects are robust, the results should be interpreted with caution due to several limitations. Firstly, the high income inequality in Serbia, measured using the SILC data, may reflect performance of the economic and social system, but it can also be driven by the features of the survey - e.g., SILC does not take into account consumption of homemade products, which is relatively sizeable in many CEE countries (including Serbia), thus potentially overstating the inequality. Secondly, we estimate the top-decile efficiency losses in terms of the working hours. However, if the efficiency was measured using their output instead of the number of working hours, it is expected that the negative effects on the top of the distribution would be larger, assuming that income is strongly (positively) linked to productivity. Thirdly, the results are influenced to a certain extent by the parameterization of the progressive income tax scenario, which mostly redistributes income from the top income earners. If the progressive tax scheme was designed so as to redistribute the tax burden not only to the top decile, but rather to a wider cohort (e.g., to the top quintile), the net labour supply effects would be less positive, which would also affect the social welfare outcomes. In addition, progressive taxation does not only affects labour decisions, but it can also have adverse effects on other aspects of economic behaviour, such as savings and human capital formation. Estimating these (non-labour) responses to taxation is beyond the scope of this paper, but it should be noted that the negative effects of progressive taxation on social welfare might be larger if these behavioural reactions are accounted for. It should also be pointed out that changes 
in the working hours after the tax reform are also conditional on labour demand, which is important in countries such as Serbia, where high unemployment and low participation are driven to a considerable extent by labour demand constraints. Finally, a switch from simple, flat-rate tax scheme to progressive taxation could also have an impact on tax collection and tax compliance costs, as it would trigger a significant rise in individual tax returns, thus affecting the social welfare effects of the reform.

\section{Appendices}

Appendix A1: Estimation samples - descriptive statistics

\begin{tabular}{|c|c|c|c|c|c|c|c|c|c|c|}
\hline \multirow[b]{2}{*}{ Variable } & \multicolumn{5}{|c|}{2007} & \multicolumn{5}{|c|}{2012} \\
\hline & Obs. & Mean & $\begin{array}{l}\text { Std. } \\
\text { Dev. }\end{array}$ & Min & Max & Obs. & Mean & $\begin{array}{l}\text { Std. } \\
\text { Dev. }\end{array}$ & Min & Max \\
\hline Years of education & 7,573 & 11.18 & 2.95 & 0 & 20 & 8,839 & 11.34 & 2.97 & 0 & 20 \\
\hline Working experience & 7,573 & 13.72 & 11.75 & 0 & 47 & 8,839 & 13.96 & 11.55 & 0 & 53 \\
\hline $\begin{array}{l}\text { Settlement } \\
\text { (urban = 1) }\end{array}$ & 7,573 & 0.59 & 0.49 & 0 & 1 & 8,839 & 0.63 & 0.48 & 0 & 1 \\
\hline Age & 7,573 & 40.51 & 11.74 & 18 & 64 & 8,839 & 41.16 & 11.82 & 18 & 64 \\
\hline $\begin{array}{l}\text { Marital status } \\
(\text { married }=1)\end{array}$ & 7,573 & 0.70 & 0.46 & 0 & 1 & 8,839 & 0.60 & 0.49 & 0 & 1 \\
\hline Number of children & 7,573 & 0.61 & 0.90 & 0 & 7 & 8,839 & 0.70 & 0.92 & 0 & 3 \\
\hline Dependency ratio & 7,573 & 0.46 & 0.53 & 0 & 5 & 8,839 & 1.47 & 0.52 & 1 & 5 \\
\hline $\begin{array}{l}\text { Household status } \\
\text { (head = 1) }\end{array}$ & 7,573 & 0.33 & 0.47 & 0 & 1 & 8,839 & 0.34 & 0.47 & 0 & 1 \\
\hline $\begin{array}{l}\text { Regional } \\
\text { unemployment rate }\end{array}$ & 7,573 & 13.72 & 3.81 & 6.72 & 20.31 & 8,839 & 22.36 & 5.26 & 13.54 & 29.85 \\
\hline
\end{tabular}

Source: Authors' calculations. 


\section{Appendix A2a: Average tax rate, 2007}

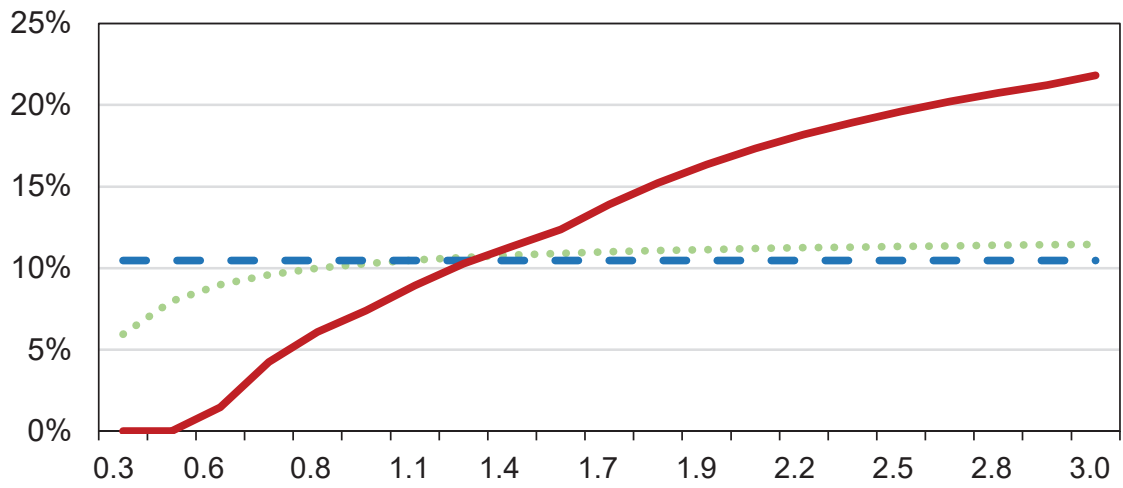

Average wage

Baseline $\quad-$ Flat tax Progressive tax

Source: Authors' calculations.

Appendix A2b: Average tax rate, 2012

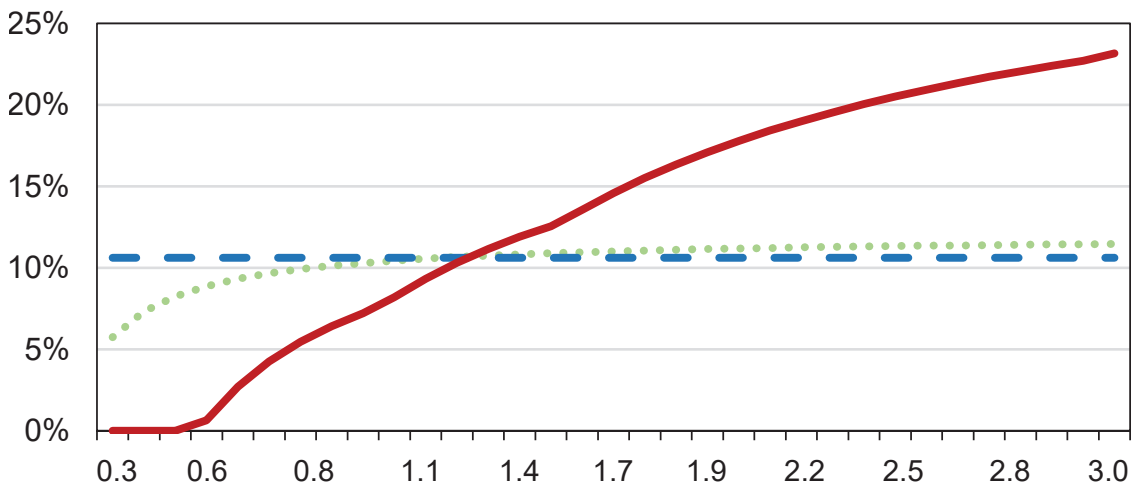

Average wage

Baseline - Flat tax Progressive tax

Source: Authors' calculations. 


\section{Appendix A3: Social welfare effects by decile (percent change) - egalitarian specification}

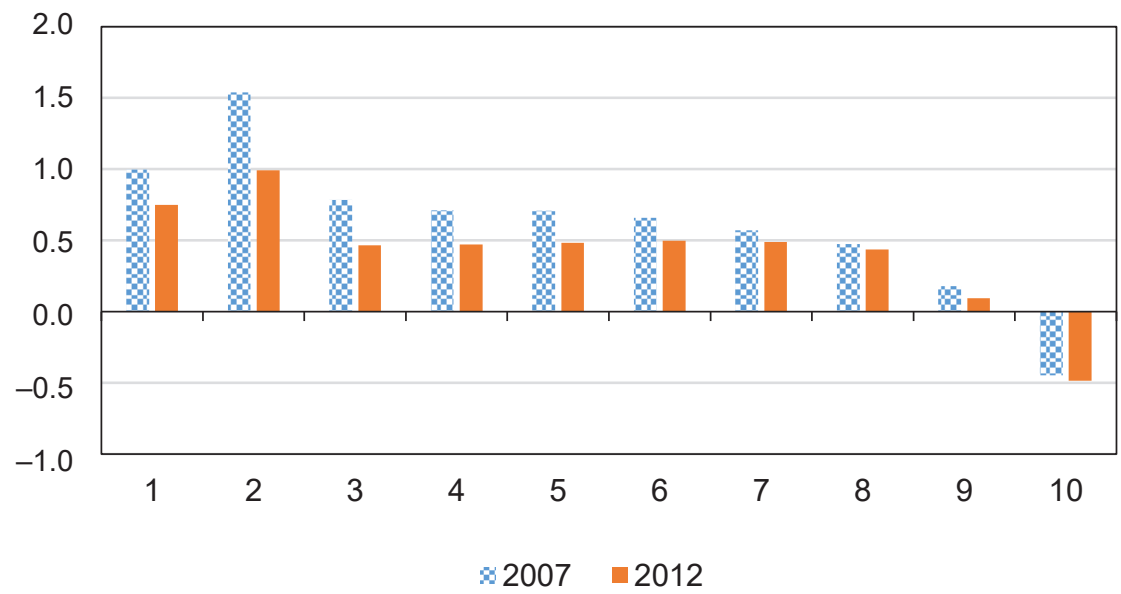

Source: Authors' calculations.

\section{References}

Albrecht, J., Navarro, L., Vroman, S. (2009). The Effects of Labour Market Policies in an Economy with an Informal Sector. The Economic Journal, 119, 1105-1129, https://doi.org/10.1111/j.1468-0297.2009.02268.x

Allingham, M. G., Sandmo, A. (1972). Income Tax Evasion: a Theoretical Analysis. Journal of Public Economics, 1(3-4), 323-338, https://doi.org/10.1016/0047-2727(72)90010-2

Alm, J., Jackson, B., McKee, M. (1992). Estimating the Determinants of Taxpayer Compliance with Experimental Data. National Tax Journal, 45(1), 107-114.

Arandarenko, M., Vukojević, M. (2008). Labour Costs and Labour Taxes in Western Balkans. The World Bank mimeo.

Atkinson, A. (1973). How Progressive Should Income Tax Be?, in Parkin, M., Nobay, A. R., eds., Essays in Modern Economics. London: Longman, pp. 90-109.

Atkinson, A. (2015) Inequality - What Can be Done? Cambridge, Massachusetts, USA: Harvard University Press. ISBN 9780674504769.

Bargain, O. (2012). Employment, Informality and Policy: Approaches and Lessons for Central and Eastern Europe. ECCU5: Activation Strategies. Scope and Priorities Report.

Bargain, O., Orsini, K., Peichl, A. (2000). Labour Supply Elasticities in Europe and the US. IZA DP 5820. 
Blundell, R. W., Duncan, A., McCrae, J., Meghir, C. (2000). The Labor Market Impact of the Working Families Tax Credit. Fiscal Studies, 21(1), 75-103, https://doi.org/10.1111/ j.14755890.2000.tb00581.x

Bourguignon, F., Gurgand, M. (2001). Fast Development with a Stable Income Distribution: Taiwan 1979-994. Review of Income and Wealth, 47(2), 139-163, https://doi.org/10.1111/1475-4991.00009

Bourguignon, F., Fournier, M., Gurgand, M. (2007). Selection Bias Corrections Based on the Multinomial Logit Model: Monte-Carlo Comparisons. Journal of Economic Surveys, 21(1), 174-205, https://doi.org/10.1111/j.1467-6419.2007.00503.x

Clotfelter, C. T. (1983). Tax Evasion and Tax Rates: an Analysis of Individual Returns. The Review of Economics and Statistics, 65(3), 363-373, https://doi.org/10.2307/1924181

Dabla-Norris, D., Kochhar, K., Suphaphiphat, N., et al. (2015). Causes and Consequences of Income Inequality: A Global Perspective. International Monetary Fund. Washington DC Working Paper No. 15/13.De Agostini, P., Paulus, A., Tasseva, I. (2015). The Effect of Tax-benefit Changes on the Income Distribution in 2008-014. EUROMOD. Working Paper No. $11 / 15$.

De Hoyos, R. (2012). Female Labour Participation and Occupation Decisions in PostNAFTA Mexico. Research in Labor Economics, 33, 85-127, https://doi.org/10.1108/ S0147-9121(2011)0000033006

Edgeworth, F.Y. (1897). The Pure Theory of Taxation. Economic Journal, 7(25), 46-70, https://doi.org/10.2307/2956958

Feldstein, M. (1995). The Effect of Marginal Tax Rates on Taxable Income: A Panel Study of the 1986 Tax Reform Act. Journal of Political Economy, 103(3), 551-572, https://doi.org/10.1086/261994

Figari, F. (2015). From Housewives to Independent Earners: How the Tax System Can Help Women to Work in a Context of Strong Familialism. Journal of Social Policy, 44(1), 63-82, https://doi.org/10.1017/s0047279414000555

Greene, W. H. (2012). Econometric Analysis. 7th ed. Upper Saddle River, NJ: Prentice Hall.

Gruber, J., Saez, E. (2002). The Elasticity of Taxable Income: Evidence and Implications. Journal of Public Economics, 84(1), 1-32, https://doi.org/10.1016/S0047-2727(01)00085-8

Hazans, M. (2011). Informal Workers across Europe: Evidence from 30 Countries. IZA. Discussion Paper No. 5871, https://doi.org/10.1596/1813-9450-5912

Heathcote, J., Storesletten, K., Violante, G. (2017). Optimal Tax Progressivity: An Analytical Framework. The Quarterly Journal of Economics, 132(4), 1693-754, https://doi.org/10.1093/qje/qjx018

Heim, B. (2007). Incredibly Shrinking Elasticities: Married Female Labour Supply 1978-002. The Journal of Human Resources, 42(4), 881-918, https://doi.org/10.3368/jhr.XLII.4.881

Lindsey, L. (1987). Estimating the Behavioral Responses of Taxpayers to Change in Tax Rates: 1982-984. With Implications for the Revenue-Maximizing Tax Rate. Journal of Public Economics, 33, 173-206. 
Löffler, M., Peichl, A., Siegloch, S. (2014). Structural Labor Supply Models and Wage Exogeneity. eutsches Institut für Wirtschaftsforschung (DIW). Berlin SOEP Working Papers No. 675.

Mankiw, N. G., Weinzierl, M., Yagan, D. (2009). Optimal Taxation in Theory and Practice. Journal of Economic Perspectives, 23(4), 147-174, https://doi.org/10.1257/jep.23.4.147

Mascarola, F., Colombino, U., Figari, F., et al. (2015). Shifting Taxes from Labour to Property: Simulation under Labour Market Equilibrium. Center for Economic and Policy Research. Working Paper No. 149/15.

McFadden, D. (1974). Conditional Logit Analysis of Qualitative Choice Behavior, in Zarembka, P., ed., Frontiers in Econometrics. New York: Academic Press.

Mirrlees, J. (1971). An Exploration in the Theory of Optimum Income Taxation. The Review of Economic Studies, 38(2), 175-208, https://doi.org/10.2307/2296779

OECD (2011). Divided We Stand: Why Inequality Keeps Rising. OECD Publishing, https://doi.org/10.1787/9789264119536-en

Pauna, B. (2004). Modelling the Participation of Households and Firms in Formal and Informal Economic Activities. Romanian Journal of Economic Forecasting, 1(4), 5-20.

Piketty, T. (2014). Capital in the Twenty-first Century. Cambridge Massachusetts: The Belknap Press of Harvard University Press. ISBN 9780674430006.

Randelovic, S., Žarković-Rakić, J. (2013). Improving Working Incentives: Evaluation of Tax Policy Reform Using SRMOD. International Journal of Microsimulation, 61, 157-176.

Rawls, J. (1971). A Theory of Justice. Cambridge, MA: Harvard University Press.

Saez, E. (2001). Using Elasticities to Derive Optimal Income Tax Rates. Review of Economic Studies, 68(1), 205-229, https://doi.org/10.1111/1467-937X.00166

Sen, A. (1973). On Economic Inequality. Clarendon Press. ISBN 9780198281931.

Sen, A. (1985). Social Choice and Justice: A Review Article. Journal of Economic Literature, 23(4), 1764-1776.

Slemrod, J., Bakija, J. (2001). Growing Inequality and Decreased Tax Progressivity, in Kevin, A. H., Glenn Hubbard, R., eds., Inequality and Tax Policy. Washington, DC: AEI Press, pp. 192-226.

Spadaro, A., Mangiavacchi, L., Piccoli, L. (2012). Optimal Taxation, Social Contract and the Four Worlds of Welfare Capitalism. Paris School of Economics. Working Paper No. 2008-38.

Stanovnik, T., Verbič, M. (2013). Earnings Inequality and Tax Progressivity in Slovenia, 1991-2009. Acta Oeconomica, 63(4), 405-421, https://doi.org/10.1556/ AOecon.63.2013.4.1

Statistical Office of the Republic of Serbia - SORS (2008). Living Standards Measurement Study: Serbia 2002-007. Belgrade: Statistical Office of the Republic of Serbia.

Statistical Office of the Republic of Serbia - SORS (2015). Srbija - prihodi i uslovi života 2013. Beograd: Statistical Office of the Republic of Serbia. 
Stern, N. H. (1976). On the Specification of Models of Optimal Taxation. Journal of Public Economics, 6(1-2), 123-162, https://doi.org/10.1016/0047-2727(76)90044-x

Stern, N. H. (1987). The Theory of Optimal Commodity and Income Taxation: An Introduction, in Newbery, D., Stern, N., eds., The Theory of Taxation for Developing Countries. Oxford, UK: Oxford University Press, pp. 22-59. ISBN 0195204980.

Stiglitz, J. E. (2012). The Price of Inequality: How Today's Divided Society Endangers Our Future. New York: W.W. Norton \& Co.

van Soest, A. (1995). Structural Models of Family Labor Supply: a Discrete Choice Approach. Journal of Human Resources, 30(1), 63-88, https://doi.org/10.2307/146191

Verbist, G., Figari, F. (2014). The Redistributive Effect and Progressivity of Taxes Revisited: An International Comparison Across the European Union. FinanzArchiv: Public Finance Analysis, 70(3), 405-429, https://doi.org/10.1628/001522114×684529

Žarković-Rakić, J., Randelović, S., Vladisavljević, M. (2016). Labour Market Effects of Social Security Contributions Reform in Serbia. Economic Annals, 61(208), 73-91, https://doi.org/10.2298/eka1608073z 